\title{
PENDAMPINGAN PENGGUNAAN GEOGEBRA UNTUK GURU MATEMATIKA SMP/MTS SE KECAMATAN TALANG KABUPATEN TEGAL
}

\section{TEACHER TRAINING OF THE USE OF GEOGEBRA FOR SMP/ MTS MATHEMATICS TEACHERS IN SUBDISTRICT TALANG, TEGAL}

\author{
${ }^{1)}$ Dian Nataria Oktaviani, ${ }^{2)}$ Rizqi Amaliyakh Sholikhakh, ${ }^{3)}$ Herani Tri Lestiana \\ 1) 2) ${ }^{3}$ Program Studi Pendidikan Matematika \\ Universitas Pancasakti Tegal \\ Jalan Halmahera Km 1 Tegal \\ 1)dian85nataria@gmail.com
}

\begin{abstract}
ABSTRAK
Kegiatan ini mempunyai tujuan sebagai berikut: 1) Meningkatnya pengenalan dan pemahaman guru matematika SMP/MTs di Kecamatan Talang Kabupaten Tegal berkenaan dengan penggunaan geogebra dalam pembelajaran matematika. 2) Meningkatnya keterampilan guru matematika SMP/MTs di Kecamatan Talang Kabupaten Tegal dalam menggunakan geogebra dalam pembelajaran matematika di kelas. Metode yang digunakan dalam kegiatan ini adalah 1) Pendidikan masyarakat dengan memberikan materi mengenai pengenalan dan penggunaannya melalui ceramah. 2) Metode pelatihan dilakukan dengan mendemontrasikan geogebra serta mendampingi guru mengenai penggunaan geogebra untuk materi matematika SMP di kelas. Luaran yang diperoleh dari kegiatan ini adalah 1) adanya peningkatan pemahaman guru matematika SMP/MTs di Kecamatan Talang mengenai penggunaan geogebra. 2) meningkatnya keterampilan guru matematika SMP/MTs di Kecamatan Talang untuk menggunakan geogebra dalam pembelajaran di kelas.
\end{abstract}

Kata kunci: Pendampingan, Geogebra, Matematika, SMP

\section{ABSTRACT}

In this activity, the mathematics teachers of SMP / MTs in Talang Subdistrict,Tegal Regency were given a training of how to use Geogebra and how to integrate Geogebra in teaching anf learning process. This activity had the following objectives: 1) Increasing teachers' understanding of the application of Geogebra in teaching and learning mathematics. 2) Increasing teachers' skill in using Geogebra in the teaching process. The method used in this activity were 1) A lecture by providing material about the introduction of Geogebra and its' application. 2) The training method, which was done by demonstrating the use of Geogebra and guiding the teachers about the use of Geogebra in teaching junior school mathematics. The result obtained from this activity were 1) an increase ofteachers' understanding about the use of Geogebra. 2) an improvement of the teachers' skill in using and employing Geogebra in the teaching process.

Keywords: Training, Geogebra, Mathematics, SMP

\section{Submited : 3 September $2017 \quad$ Revision : 27 Februari 2018 Accepted : 9 Maret 2018}

\section{PENDAHULUAN}

Geogebra merupakan software matematika yang masih jarang digunakan oleh sebagian besar guru matematika SMP/MTs se Kecamatan Talang
Kabupaten Tegal. Keterbatasan wawasan guru dalam mengenai Geogebra merupakan salah satu faktor dalam program kemitraan masyarakat di Kecamatan Talang.S alah satu faktornya 
adalah terbatasnya intensitas atau penyelenggara pelatihan mengenai software matematika yang diikuti oleh guru matematika di lingkungan Kecamatan Talang Kabupaten Tegal. Dampaknya sebagian besar guru matematika masih terbatas dalam membuat variasi pembelajaran di kelas. Variasi pembelajaran dapat berupa model pembelajaran dan media pembelajaran dengan menggunakan geogebra maupun software matematika lain.

Salah satu alternatif dalam variasi pembelajaran matematika di kelas adalah dengan menggunakan geogebra. Software GeoGebra salah satu altenatif media pembelajaran matematika yang memberikan pengalaman visual kepada siswa dalam berinteraksi dengan konsepkonsep geometri. Pemilihan penggunaan software yang tepat dalam pembelajaran matematika diharapkan dapat membantu meningkatkan kemampuan belajar matematika yang rendah bagi siswa SMP/MTs di Kecamatan Talang.

Program kemitraan masyarakat dilakukan dengan kerja sama 5 sekolah mitra diantaranya yaitu SMP N 1 Talang, SMP Walisongo Talang, SMP Plus NU 1 Penawaja, MTs Mambaul Hikmah Talang, MTs NU Wahid Hasyim Talang. Kondisi 5 sekolah mitra mempunyai kondisi yang berbeda. Kurikulum yang digunakan berbeda dari 5 sekolah mitra, 1 sekolah mitra yaitu SMP Negeri 1 Talang menggunakan kurikulum 2013 dan 4 sekolah mitra yang lainnya menggunakan kurikulum KTSP. Kemampuan matematika yang dimiliki siswa dari 5 sekolah mitra mempunyai kondisi berbeda. Siswa di SMP Negeri 1 Talang mempunyai kemampuan matematika lebih baik dari 4 sekolah mitra yang lain dikarenakan salah satunya seleksi nilai penerimaan siswa yang lebih tinggi dibandingkan sekolah lainnya. Salah satu faktor kemampuan matematika siswa rendah adalah minat belajar matematika yang rendah dari sebagian besar siswa.

\begin{tabular}{lccr}
\multicolumn{3}{c}{ Pendampingan } & penggunaan \\
geogebra untuk & guru matematika \\
SMP/MTs & se & Kecamatan & Talang
\end{tabular}

Kabupaten Tegal diharapkan mampu meningkatkan keterampilan guru dalam variasi pembelajaran serta kreatifitas guru. Dampaknya guru dapat menggunakan geogebra di kelas sebagai salah satu alternatif untuk meningkatkan minat belajar siswa.Penggunaan media dengan perangkat komputer dalam pembelajaran diharapkan juga akan mampu meningkatkan motivasi belajar siswa. Hal ini disebabkan karena siswa akan belajar secara aktif melalui interaksi langsung dengan alat tersebut, melakukan eksplorasi terhadap konsep yang sedang dipelajari (Suweken, 2013). Kegiatan pendampingan ini bertujuan untuk meningkatkan keterampilan guru dalam penggunaan geogebra di kelas sehingga siswa mampu dengan mudah memahami konsep matematika.

\section{METODE}

Kegiatan ini menggunakan metode pendidikan masyarakat, pelatihan serta pendampingan. Pendidikan masyarakat dengan memberikan materi mengenai pengenalan dan penggunaannya melalui ceramah. Metode pelatihan dilakukan dengan mendemonstrasikan geogebra serta mendampingi guru mengenai penggunaan geogebra untuk materi matematika SMP di kelas.

Kelompok sasaran kegiatan ini adalah guru matematika di Kecamatan Talang yang berjumlah 14 orang dari SMP Negeri 1 Talang berjumlah 6 orang, SMP Walisongo Talang berjumlah 2 orang, SMP Plus NU 1 Penawaja berjumlah 2 orang, MTs Mambaul Hikmah. Talang berjumlah 2 orang, MTs NU Wahid Hasyim Talang berjumlah 2 orang. 


\section{HASIL DAN PEMBAHASAN}

Hasil kegiatan ini adalah sebagai berikut.

1. Meningkatnya pengenalan dan pemahaman guru berkenaan dengan penggunaan geogebra dalam pembelajaran matematika.Kegiatan ini bertujuan membekali guru untuk memahami penggunaan geogebra dengan harapan dapat menerapkan dalam pembelajaran di kelas. Geogebra dapat digunakan salah satu alternatif variasi pembelajaran sebagai upaya untuk meningkatkan kemampuan pemahaman konsep siswa.

2. Meningkatnya keterampilan guru dalam menggunakan geogebra dalam pembelajaran matematika di kelas.Mendemonstrasikan teknologi pembuatan media pembelajaran matematika menggunakan software geogebra.Materi Himpunan, Bilangan, Titik, garis dan sudut disampaikan oleh Dian Nataria Oktaviani, S.Si., M.Pd. Pembimbingan dan praktek pembuatan media pembelajaran matematika dengan menggunakan geogebra materi fungsi yang disampaikan oleh Rizqi Amaliyakh Sholikhakh, M.Pd. Pembimbingan cara penggunaan media pembelajaran berbasis teknologi dalam pembelajaran matematika di kelas

3. Selama proses pelatihan penggunaan geogebra $90 \%$ peserta dapat mempraktekan geogebra untuk materi himpunan, fungsi, garis lurus, transformasi dan dimensi tiga. Adapun kebermanfatan dari pelatihan antara lainpeserta dimudahkan dalam soal-soal ulangan atau prediksi soal. Peserta dimudahkan dalam menyajikan materi matematika karena geogebra mampu memvisualisasikan objek-objek matematika sehingga pembelajaran di kelas lebih menyenangkan. Kendala yang dialami selama pelatihan adalah $10 \%$ peserta belum terbiasa menggunakan media komputer. Penggunaan geogebra di kelas tampak sebagai bantuan tampilan visualisasi dari masalah matematika. Siswa masih kurang aktif menggunakan geogebra di kelas karena banyaknya komputer untuk pembelajaran menggunakan geogebra masih terbatas.

4. Penguasaan geogebra oleh guru dapat dikembangkan untuk menyusun bahan ajar matematika seperti modul, lembar kerja siswa atau video pembelajaran. Penyusunan bahan ajar matematika berbantuan geogebra dapat digunakan sebagai salah satu upaya untuk membantu siswa memahami konsepkonsep matematika. Bahan ajar mempunyai beberapa peranan dalam pembelajaran yaitu sebagai penyedia informasi dasar yang masih bisa dikembangkan agar gurutidak terlalu mendominasi pembelajaran (Prastowo, 2011).

5. Kegiatan pendampingan penggunaan geogera di kelas.Adanya visualisasi sederhana dari geogebra yang disampaikan oleh guru memungkinkan siswa untuk memudahkan siswa untuk dapat menemukan, mengemukakan, dan membuat representasi matematis dari ide atau gagasan matematis yang dimiliki siswa. Hal ini sesuai dengan pendapat Nopiyani (2018) yaitu adanya respon positif dari siswa terhadap pembelajaran matematika berbantuan GeoGebra.Melalui bantuan penggunaan geogebra dalam pembelajaran matematika di kelas salah satu siswa mencoba menyelesaikan permasalahan matematika yang disampaikan oleh guru tersebut. Hal ini sesuai dengan pendapat Suweken (2013) siswa mendapatkan kesempatan lebih banyak lagi untuk melihat dan mmengeksplorasi konsep-konsep matematika secara visual. Melalui tampilan visualisasi dari geogebra yang terdapat pada gambar dan gerakan dapat mengembangkan memori visual anak (Atikasari, 2015). Penggunaan geogebra ini bertujuan untuk memudahkan siswa 
dalam memahami pemahaman konsep matematika oleh siswa melalui tampilan geogebra yang diberikan oleh guru.

6. Dampak dari kegiatan ini adalah penguasaan geogebra oleh guru. Guru dapat menerapkan geogebra di kelas. Penggunaan geogebra sebagai salah satu alternatif media pembelajaran matematika yang dapat memotivasi dalam mengikuti pembelajaran. Hal ini sesuai dengan pendapat Putri (2014) yang menyatakan perangkat pembelajaran yang berbantuanGeoGebra juga efektif meningkatkan aktivitas siswa dan memotivasi siswa dalam mengikuti pembelajaran.Penerapan geogebra dalam pembelajaran di kelas dapat meningkatkan minat belajar matematika peserta didik(Putro, 2016).

\section{SIMPULAN}

Berdasarkan hasil kegiatan dapat disimpulkan bahwa variasi pembelajaran matematika dapat dilakukan dengan penggunaan software matematika yaitu geogebra.Tahapan yang dilakukan untuk meningkatkan pengenalan dan pemahaman berkenaan dengan geogebra kepada guru matematika SMP/MTs di Kecamatan Talang Kabupaten Tegal melalui pendidikan masyarakat. Pada tahapan ini $90 \%$ peserta pendidikan masyarakat yaitu 14 dari 15 guru SMP/MTs di Kecamatan Talang Kabupaten Tegal telah mengenal dan paham berkenaan dengan penggunaan geogebra. Tahapan berikutnya untuk meningkatkan keterampilan guru dalam menggunakan geogebra di kelas dilakukan pelatihan dan pendampingan penggunaan geogebra di kelas.Pada tahapan ini terdapat kendala yaitu penggunaan geogebra di kelas tampak sebagai bantuan tampilan visualisasi dari masalah matematika.Siswa masih kurang aktif menggunakan geogebra di kelas karena banyaknya komputer untuk pembelajaran menggunakan geogebra masih terbatas.

\section{DAFTAR PUSTAKA}

Atikasari, G., \& Kurniasih, A. W. (2015). Keefektifan Model Pembelajaran Kooperatif dengan Strategi TTW Berbantuan Geogebra Terhadap Kemampuan Berpikir Kreatif Matematis Siswa Kelas VII Materi Segitiga. Unnes Journal of Mathematics Education, 4(1).85-94

Putri, NWS, Sariyasa, Ardana. I.M., (2014). Pengembangan Perangkat Pembelajaran Tandur Berbantuan Geogebra Sebagai Upaya Meningkatkan Prestasi Dan Aktivitas Belajar Geometri Siswa. e-Journal Program Pascasarjana Universitas Pendidikan Ganesha Program Studi Matematika, 3, ( 2014)

Nopiyani, D., Turmudi, T., \& Prabawanto, S. (2018).Penerapan Pembelajaran Matematika Realistik Berbantuan GeoGebra untuk Meningkatkan Kemampuan Komunikasi Matematis Siswa SMP. Mosharafa : Jurnal Pendidikan Matematika, 5(2), 45-52.

Prastowo, A, (2011). Panduan Kreatif membuat Bahan Ajar Inovatif. Yogyakarta: Diva Press

Putro, K. I. R. S. (2016). Pemanfaatan APBS dan Geogebra untuk meningkatkan Minat dan Hasil Belajar Matematika di SMP. Manajemen Pendidikan, 11(1), 49-58.

Riyanti, R., Sutama, S., \& Maryadi, M. (2017). Manajemen Pembelajaran Matematika di SD Negeri Mangkubumen 83 Surakarta. Jurnal Varidika, 29(1), 65-74.

Suweken, G. (2013). Pengintegrasian Media Pembelajaran Virtual Berbasis Geogebra Untuk Meningkatkan Keterlibatan Dan Pemahaman Konsep Matematika Siswa Kelas VIII SMPN 6 Singaraja. JPI (Jurnal Pendidikan Indonesia), 2(2). 276-285 